\title{
Palynological evidence for the age of Tertiary basalts and post-basaltic sediments at Kap Dalton, central East Greenland
}

\author{
N. J. Soper and L. I. Costa
}

Small outliers of sedimentary rocks overlying the Tertiary basalts of the northern Blosseville Kyst are preserved in down-faulted areas at Kap Dalton and Savoia Halvø (Kap Brewster) (Watt et al., this report). They are of particular interest in that their age establishes a younger limit for the period of effusive vulcanity on this sector of the East Greenland continental margin.

\section{Structure and succession at Kap Dalton}

The Kap Dalton sediments are preserved in a down-faulted block or small graben to the south-east of a major coast-parallel normal fault which has a throw of at least $1500 \mathrm{~m}$ (fig. 40). Outside the graben a thick, sub-horizontal succession of dominantly subaerial basalt flows is cut by the coastal dyke swarm. The basalts within the graben dip gently north-west and comprise two successions separated by another fault which crosses the Kap Dalton headland. The basalts of the outer headland are intruded by the dyke swarm, while those between the two faults are dyke-free and are overlain by the Kap Dalton sediments. The latter basalt succession therefore occupies a high stratigraphic position in the lava pile, above the level of dyke emplacement. About $750 \mathrm{~m}$ of 10-30 m flows are exposed. Numerous sedimentary intercalations occur between the flows. These, together with occasional pillow structures and a general absence of oxidised tops indicate that the flows consolidated in aqueous conditions.

The sedimentary horizons range from conglomerates and finer beds entirely volcanogenic in composition, through soft shales with little admixture of volcanic detritus to thin allochthonous coals.

The post-basaltic sediments at Kap Dalton are poorly exposed, but are seen to comprise two upward-fining sequences of distinct lithological type; these will, for the present, be termed informally the lower and upper sequences.

The lower sequence is about $40 \mathrm{~m}$ in thickness and includes the Cyrena Beds and basal conglomerate of Wager (1935). As Wager showed, these sediments are composed of volcanic detritus and minerals derived from basic igneous rocks of dominantly alkaline type. The Cyrena Beds are dark, often parallel-bedded arenites with several bands of marine shelly fossils; they are overlain by a thin, laminated calcareous mudstone.

The upper sequence is about $45 \mathrm{~m}$ thick and commences with the Yellow Sandstone (c. 25 m) which is composed of basement-derived quartz and feldspar with no volcanic detritus. The lower part of the sandstone is coarse, sometimes pebbly, and either cross-stratified with foreset beds inclined to the west and south, or massive with Skolithos burrows. The upper part is finer with more numerous flaggy partings. The overlying Coeloma Beds are not exposed but numerous $5-10 \mathrm{~cm}$ crab-bearing nodules occur as surface debris, together with 


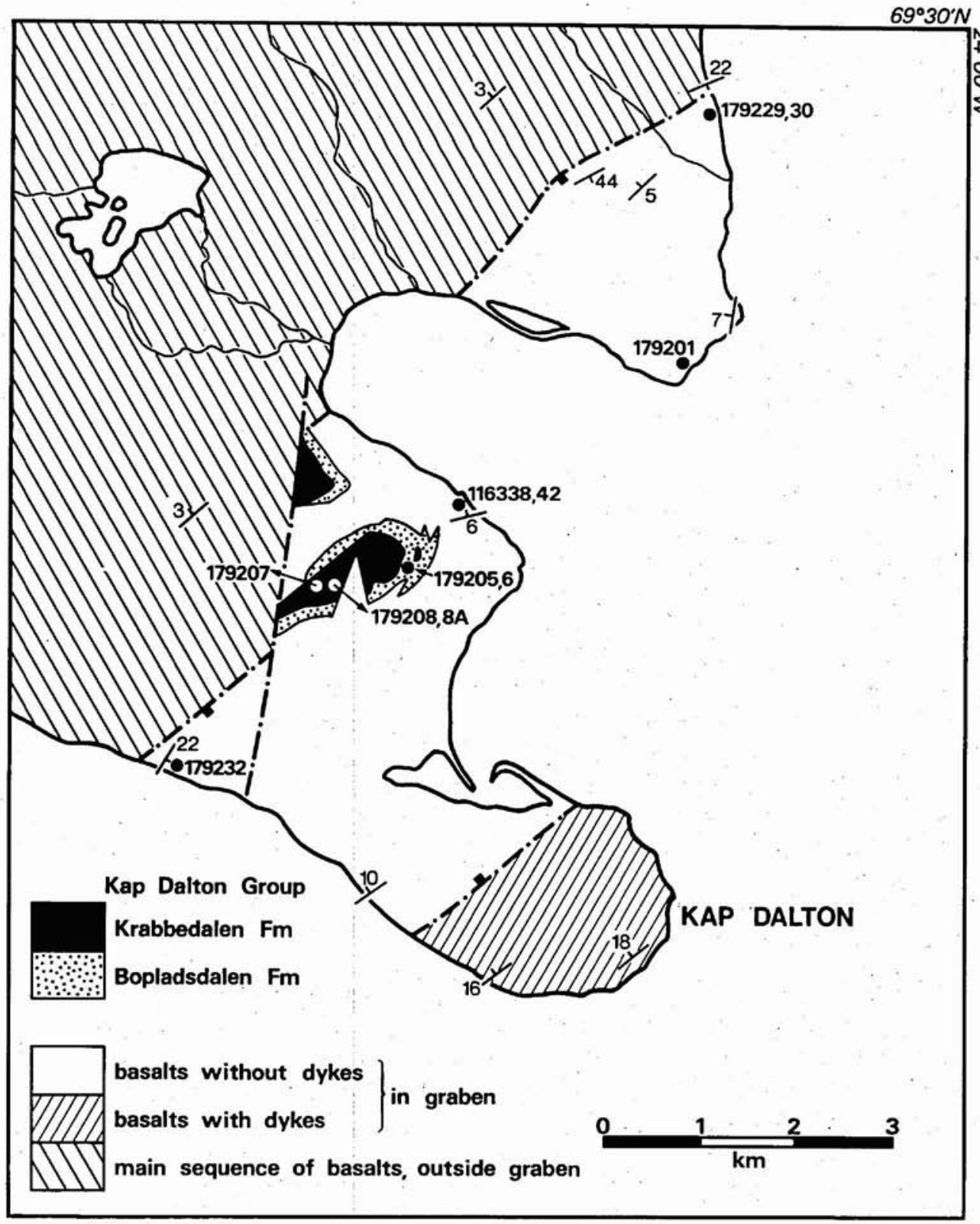

Fig. 40. Geological sketch map of the Kap Dalton graben, central East Greenland. Numbers refer to GGU samples.

fragments of laminated siltstone, Teredo-bored wood and, from a higher horizon, larger nodules with the lobster Homarus. The thin White Shale recorded by Wager at the top of the succession also occurs only as debris. 
The Kap Dalton sediments appear to dip gently north-west in conformity with the underlying basalts. The basal contact is not exposed, but at one point the conglomerate can be seen a few metres above the vesicular upper portion of the highest flow. Since the conglomerate is composed of exotic pebbles, it was not formed of material eroded from the subjacent flows. The evidence suggests that no significant unconformity need necessarily be present; this is in line with Birkenmajer's (1972) assessment of the basal relationships of the Kap Dalton Formation at Savoia Halvø. On the other hand, the abrupt change in sediment type between the lower and upper parts of the sequence suggests that a non-sequence or unconformity exists beneath the upper sequence at the base of the Yellow Sandstone.

Samples for palynological investigation were taken from all named units except the Yellow Sandstone.

\section{Palynological results}

Samples of intrabasaltic sediment and samples from the Kap Dalton sediments were prepared for palynological study. Their dating is based on the distribution of stratigraphically significant dinoflagellate cyst taxa, to which the following discussion is restricted.

\section{Intrabasaltic horizons}

GGU 116338/42, GGU 179230/32 (shales)

GGU 179201 (siltstone)

GGU 179229 (coal)

These samples all represent intrabasaltic horizons from the upper, dyke-free part of the pile at Kap Dalton. 179201 was barren and 179229,179230 and 116338 contained only plant debris and poorly preserved spores. 116342 yielded a terrestrial assemblage rich in pollen and spores, but no marine microplankton.

Sample 179232 yielded microplankton as well as abundant pollen and spores. Of the latter, terrestrial miospores are dominant, with many species representing several angiosperm groups and, in less abundance, gymnosperms and pteridophytes. Dinoflagellate cysts are well represented; of the thirty or so species present, the following are of biostratigraphic significance: Deflandrea speciosa Alberti, D. depressa Morgenroth, Wetzeliella (Apectodinium) parva Alberti, W. (Wetzeliella) meckelfeldensis Gocht, Kenleya aff. leptocerata Cookson \& Eisenack and Lingulodinium machaerophorum Deflandre \& Cookson. The dinoflagellate cyst evidence in toto indicates a basal Ypresian age, close to the Paleocene-Eocene boundary.

\section{Kap Dalton sediments lower sequence}

\section{GGU 179205 (Cyrena Beds)}

GGU 179206 (calcareous mudstone above Cyrena Beds)

These samples are from the lower sequence of the Kap Dalton sediments. 179206 proved poor in organic remains. 179205 yielded abundant palynomorphs. Marine microplankton are 
very scarce and only about ten dinoflagellate species are represented. Of these, Deflandrea wardenensis Williams \& Downie and Wetzeliella (Wetzeliella) lunaris Gocht are significant biostratigraphically:

The dinoflagellate cysts present in sample 179205 indicate that the Cyrena Beds are Ypresian (Lower Eocene) in age. The occurrence of W. (W.) lunaris suggests, by comparison with its range in the London Clay (Williams \& Downie, 1966) an Upper Ypresian age.

\section{Kap Dalton sediments upper sequence}

GGU 179207 (White Shale)

GGU 179208 (Matrix of Coeloma Beds)

GGU 179208A (crab nodule from Coeloma Beds)

Of these samples from the upper sequence of Kap Dalton sediments, 179207 and 179208 were almost barren of organic remains. $179208 \mathrm{~A}$ produced a very rich palynological assemblage, with over thirty species of dinoflagellate cysts. The following are stratigraphically significant: Cannosphaeropsis pusulosa Morgenroth, Chiropteridium dispersum Gocht, $C$. lobospinosum Gocht, Cyclonephelium incultum Morgenroth, C. semicirculatum Morgenroth, Pentadinium taeniagerum Gerlach, Pterodinium circumsutum Morgenroth and Thalassiphora reticulata Morgenroth. All these species indicate an Oligocene age. Five of the species listed above are thought to be restricted to the Lower Oligocene (Cannosphaeropsis pusulosa, Cyclonephelium incultum, C. semicirculatum, Pterodinium circumsutum and Thalassiphora reticulata) and only Chiropteridium lobospinosum and Pentadinium taeniagerum appear to indicate a Middle or Upper Oligocene age. The presence of Areosphaeridium diktyoplokus (Klumpp), an Eocene-LowerOligocene species, seems to confirm a Lower Oligocene age for the Coeloma Beds.

\section{Conclusions}

(1) The age of the upper part of the basalt sequence exposed in the vicinity of Kap Dalton is basal Ypresian, close to the Paleocene-Eocene boundary. Taken in conjunction with the Lower Sparnacian (late Paleocene) age for the base of the much thicker basalt succession in the Kangerdlugssuaq area (Soper et al., 1976), this evidence shows that the basalt pile was erupted over a relatively short period-a few million years at most-in latest Paleocene time.

(2) An Upper Ypresian (Lower Eocene) age is assigned to the lower sequence of postbasaltic sediments at Kap Dalton. Bearing in mind that the stratigraphic position of the dated intrabasaltic shale (GGU 719232) is some $300 \mathrm{~m}$ below the base of the Kap Dalton sediments, it is clear that little, if any, of the upper part of the basalt pile was removed by erosion prior to the deposition of the Cyrena Beds.

(3) The Oligocene (probably Lower Oligocene) age for the upper part of the Kap Dalton sediments confirms the presence of an important non-sequence (or low-angle erosional unconformity) within the succession, probably at the base of the Yellow Sandstone. 


\title{
Acknowledgements
}

We thank Prof. C. Downie for helpful comments, L.I.C. acknowledges financial support from the British Council.

\section{References}

Birkenmajer, K. 1972: Report on investigations of Tertiary sediments at Kap Brewster, Scoresby Sund, East Greenland. Rapp. Grønlands geol. Unders. 48, 85-91.

Soper, N. J., Higgins, A. C., Downie, C., Matthews, D. W. \& Brown, P. E. 1976: Late Cretaceous early Tertiary stratigraphy of the Kangerdlussuaq area, east Greenland, and the age of opening of the north-east Atlantic. Jl geol. Soc. Lond. 132, 85-104.

Wager, L. R. 1935: Geological investigations in East Greenland, Part II: Geology of Kap Dalton, Meddr Grønland 105,3, 32 pp.

Williams, G. L. \& Downie, C. 1966: Wetzeliella from the London Clay. In Davey, R. J., Downie, C., Sargeant, W. A. S. \& Williams, G. L. Studies on Mesozoic and Cainozoic dinoflagellate cysts. Bull. Br. Mus. nat. Hist. (Geol.), Suppl. 3, 182-198.

Department of Geology, The University of Sheffield,

Mappin Street,

St. George's Square, Sheffield SI 3JD,

U.K.

\section{Progress report on geochronological investigations in the crystalline complexes of the East Greenland Caledonian fold belt between $72^{\circ}$ and $74^{\circ} \mathrm{N}$}

\author{
D. C. Rex, A. R. Gledhill and A. K. Higgins
}

In the summer of 1974 two of the authors (D. C. R. \& A. R. G.) collected samples from various crystalline units in the inner fjord region of the Caledonian fold belt between $72^{\circ}$ and $74^{\circ} \mathrm{N}$, with a view to testing current hypotheses of the geological history of the region. The only dates so far available from this region are a few K-Ar mineral ages reported by Haller \& Kulp (1962) all of which reflect Caledonian orogenesis. In the Scoresby Sund region isotopic work on crystalline units comparable to some of those reported on here has yielded Archaean and middle Proterozoic as well as Caledonian ages (Hansen et al., 1973, 1974; Rex \& Gledhill, 1974; Friderichsen \& Higgins, this report).

Results are presented in this report of whole rock $\mathrm{Rb}-\mathrm{Sr}$ analyses and $\mathrm{K}-\mathrm{Ar}$ analyses obtained using standard techniques (Van Breemen \& Dodson, 1972; Rex \& Dodson, 1970). The localities from which the suites of samples were collected are shown on fig. 32 (localities A-E). 